\title{
Antoni Dębiński
}

\section{Poena cullei w rzymskim prawie karnym}

Prawo Kanoniczne : kwartalnik prawno-historyczny 37/3-4, 133-146

1994

Artykuł został zdigitalizowany i opracowany do udostępnienia w internecie przez Muzeum Historii Polski w ramach prac podejmowanych na rzecz zapewnienia otwartego, powszechnego i trwałego dostępu do polskiego dorobku naukowego i kulturalnego. Artykuł jest umieszczony w kolekcji cyfrowej bazhum.muzhp.pl, gromadzącej zawartość polskich czasopism humanistycznych i społecznych.

Tekst jest udostępniony do wykorzystania w ramach dozwolonego użytku. 


\section{ANTONI DĘBIŃSKI}

\section{POENA CULLEI W RZYMSKIM PRAWIE KARNYM}

1. Kara skórzanego worka (poena cullei) ${ }^{1}$ była jednym ze sposobów wykonania kary głównej w starożytnym Rzymie. Stosowano ją za ojcobójstwo lub matkobójstwo a później także za zabójstwo innych osób bliskich (parricidium) ${ }^{2}$. Skazani za te przestępstwa byli zaszywani w worku wraz ze zwierzętami i wrzucani do morza. Egzekucja poprzedzona była wykonaniem bardzo osobliwych rytów, zupełnie nieznanych w przypadku innych form kary śmierci. Zainteresowanie tą problematyką nasuwa przede wszystkim pytania o pochodzenie i znaczenie zwyczaju zaszywania zwierząt wraz $\mathrm{z}$ ojcobójcą, zakres zastosowania i funkcje tej kary. Odpowiedź na te i inne

1 W lacińskim języku potocznym słowo culleus (lub culeus) oznaczało skórzany pojemnik o szczelnym zamknięciu, który był przeznaczony do przechowywania i transportowania wina, oleju, octu lub innych płynów. Słowo to oznaczało także jednostkę miary dla płynów (równą 20 amforom lub 91 litrom). Dictionnaire étymologigue de la lanque latine, red. A. E r n o u t - A . M e i ll e t, t. I. Paris $1959^{4}$,v. culleus, s. 155; H i t z i g, v. culleus. Paulys Realencyklopädie der classischen Altertumswissenschaft, t. IV. 2. Stuttgard 1901, col. 1744-1747. Szerzej na temat znaczenia i zastosowania terminu culleus zob. E. $\mathrm{N}$ a r d i L'Otre dei parricidi e le bestie incluse, Milano 1980, s. $13 \mathrm{nn}$.

${ }_{2}$ Termin parricida (paricida), arch. parricidas jest złożeniem dwóch wyrazów: pater (ojciec) i caedere (ciąć, ścinać, zabić), aczkolwiek etymologia i znaczenie tego słowa są dyskutowane. W sensie właściwym termin parricida znaczy zabojcę osób bliskich (ojcobójstwo) lub morderce w ogóle. W znaczeniu przenośnym wyraz ten oznacza także zbrodniarza, zdrajce, wroga ojczyzny. A. B e r g e r, Encyclopedic Dictionary of Roman Law, Philadelphia 1953, v. parricidas, s. 618; H e u m a n n s, Handlexikon zu den Quellen des romischen Rechts, in 9. Aufl. neu bearb. von E. S e c k e 1, Gratz $1958^{10}$, v. parricidium, s. 405. Szerzej na temat etymologii slowa zob. F. de V i s c h e r. La formule paricidas esto et les origines de la juridiction criminelle à Rome. Bulletins de l'Académie royale de Belgique, Classe des Lettres, t. XIIII, Bruxelles 1927, s. 5 nn.; R. H e $\mathrm{n}$ r i o n, Paricidas, Revue belgi de Philologie et d'Histoire 20 (1941), s. $220 \mathrm{nn}$.: A. M a g d a 1 i n, Paricidas, w: Du châtiment dane la cité (tabl ronde), Rome 1984, s. 549-571; P. M e y l a n, L'étymologie du mot parricide à travers la formule "Paricidas esto" de la loi romaine, Lausanne 1928. s. $7 \mathrm{nn}$. Na temat ewolucji znaczenia przestepstwa parricidium w prawie klasycznym i poklasycznym, zob. H. K u p i s z e w s $\mathrm{k}$ i, Quelques remarques sur le parricidium dans le droit romain classique et post-classique. St. Volterra. t. IV, Milano 1971, s. $602 \mathrm{nn}$. 
pytania wymaga obszernego studium ${ }^{3}$; w niniejszym artykule przedstawiamy jedynie kilka refleksji na ten temat.

Lektura źródeł prawniczych i świadectw pisarzy starożytnych pozwala odtworzyĄ szczególną i symboliczną procedurę jaką stosowano podczas wykonania kary poena cullei.

Otóż skazany na śmiera, po uprzednim wychłostaniu czerwonymi rózgami $^{4}, \mathrm{z}$ głową owiniętą $\mathrm{w}$ skórę wilczycy ${ }^{5}, \mathrm{z}$ drewnianymi sabotami na stopach $^{6}$ był osadzany w więzieniu. Następnie zaszywano go żywego w worek $(\text { culleo })^{7}$ z bydlęcej skóry wraz ze zwierzętami, wężem, małpą, psem

${ }^{3}$ Karę skórzanego worka omawiają podręczniki rzymskiego prawa karnego: Th. M o m m s e n, Römisches Strafrecht, Leipzig 1899 (Nachdr. Graz 1955), s. 923 nn; W. R e i n, Das Kriminalrecht der Römer von Romulus bis auf Justynian, Leipzig 1844 (Neudr. Darmstadt 1962) s. 457 i nn. Z prac dotyczących funkcji tej kary i znaczenia rytów jej towarzyszących należy wymienić opracowanie R. D üll a (Zur Bedeutung der poena cullei na römischen Strafrecht, Atti del Congresso internationale di diritto romano, t.I. Pavia 1935, s. $363 \mathrm{nn}$.) i niedawno opublikowaną pracę E. C a n $\mathrm{t}$ a r e $11 \mathrm{i}$ (Il supplizi capitali in Grecia e a Roma, Milno 1991, s. 264 nn.).

4 D. 48. 9, 9 pr. (Modestinus): virgis sanguineis verberatus. Smaganie skazanego czerwonymi rózgami nie stanowiło zwyczajnej chłosty poprzedzającej wykonanie śmierci. Ryt ten jak się przyjmuje w literaturze, miał znaczenie symboliczne-magiczne: wyrażał on oczyszczenie społeczności ze zła i przeniesienie go na skazanego, aby zginęło wraz z nim. Cantarella, op. cit., s. 279 nn: D ü 1 1, op. cit., s. 396 nn. Obszerną analizę tego rytu $\mathrm{w}$ religii rzymskiej przedstawia $\mathrm{J}$. B a y e $\mathrm{t}$, Le rite du féciat et le cornouiller magique. Mélanges d'archéologie et d'histoire $52(1935)$, s. $65 \mathrm{nn}$.

${ }^{5}$ Rhet ad Her. 1. 13, 23: folliculo lupino os obvolutum est: Cic. de inv. 2, 50, 148; os autem obvolutum est folliculo et praeligatum. (Skróty oznaczające źródła literackie są podane wedlug sposobu przyjętego przez M.K a s e r a, Das römische Privatrecht, t. I. München 1971, s. 827-833; t. II. München 1975, s. 679-680).

Znaczenie tego szczególnego rytualu doczekało się wiẻlu interpretacji. Wyjaśnienie Cycerona (De inv. 2. 50. 149), które przyjmuje także G. H u m b e r t (v. culeus. Dictionnaire des antiquités grecques et romains, t. I. 1. Paris 1887, s. 1579), że kaptur $\mathrm{z}$ wilczej skóry razem $\mathrm{z}$ drewnianymi trepami miały uniemożliwić skazanemu ucieczkę. nasuwa poważne wątpliwości. Niewątpliwie Rzymianie zastosowaliby inny, bardziej funkcjonalny i skuteczny sposób. Innym wythumaczeniem jest teza o rytualnym znaczeniu tego aktu. Przebranie za wilka mogło stanowić ryt przejścia. Okrycie glowy ojcobójcy oznaczała wyjście przestępcy poza granice spoleczności ludzkiej. Najbardziej przekonywująca jest interpretacja symboliczna. Ojcobójca zakryty wilczą maską otrzymywał wygląd okrutnej i nieludzkiej bestii, której cechy ujawniały jego czyn. Dodatkowo zakrycie głowy wilczą skórą oznaczalo także akt izolacji skazanego. C a $n \mathrm{t}$ a r e 11 a, op. cit. s. 276: D ü $\mathrm{H}$, op. cit. s. 369.

6 Auct. ad Her. 1. 13, 23: soleae ligenae pedibus inductae sunt: Cic. de inv. 2. 50, 158; ligneae soleae in pedes inditae sunt. Założenie skazańcowi drewnianych butów mialo także symboliczne znaczenie. Drewno, z którego wykonane były drewniaki, uważane bylo przez Rzymian za material izolujący. Soleae lingeae mialy uniemożliwić zatem splamienie, zbrukanie ziemi poprzez kontakt ojcobójcy z nią. C a $\mathrm{n} t$ a $\mathrm{r}$ e $\mathrm{ll}$ a, op. cit. s. 278 nn: D ü 11 , op. cit. s. 339.

7 Por. np. Sen. contr. 7, 2, 3: si damnatus esses, carnifex te culleo tum insuisset; Sen. de clem. 1,23,1: culleo insuit: C. Th. 9. 15, 1: insutus culleo. Skórzany worek najczęściej byl określany terminem culleus, tak nazywały go źródła prawne. Teksty literackie niekiedy na jego określenie używały terminu corio (np. Auct. ad Her. 1, 13, 26; Iuv. 13, 156). 
i kogutem. Później transportowano skazanego na brzeg morza i wrzucano do wody ${ }^{8}$. Jeśli w pobliżu nie było morza, precyzowała ustawa, ojcobójce należało wrzucić do rzeki ${ }^{9}$. Skazany odbywal tẹ ostatnią podróż wozem zaprzężonym w czarne woły ${ }^{30}$.

W Rzymie zabójsto matki lub ojca bylo traktowane jako czyn niewiarygodny i wręcz przeciwny naturze (prodigii ac portenti simile ${ }^{11}$ ). Ten, kto zamordował rodziców, był traktowany bardziej jako monstrum ${ }^{12}$ niż winny. Jak powszechnie przyjmuje się obecnie w literaturze rytuał kary worka był, przynajmniej początkowo, utożsamiany $z$ religijnym rytem procuratio prodi$g i^{13}$. Miał on na celu usunięcie monstrum ze spoleczności ludzkiej a przez to samo naprawienie relacji pomiędzy światem ludzkim i światem bogów. Poprzez karę worka oczyszczano społeczność miasta ze zmazy, która została ściągnięta przez przestępstwo parricidium ${ }^{14}$.

Stosując karę śmierci poprzez hermetyczne zaszycie w worku i wrzucenie do wody pozbawiano ojcobójcę prawa do pochówku, ale również, czy przede wszystkim kontaktu z podstwawowymi elementami wszechświata: powietrzem, ziemią i wodą. Te funkcje kary wskazuje Cyceron opisując tragiczne polożenie ojcobójców: ,żyją, ale bez-możliwości oddychania powietrzem niebieskim; umierają, ale tak, że ziemia nie ma kontaktu $z$ ich kośćmi; są

${ }^{8}$ Zatopienie ojcobójcy w wodzie miało wielorakie znaczenie. Akt ten byl nie tylko rytem oczyszczającym i wyrazem woli pozbawienia skazanego pochówku, ale również stanowił środek uniemożliwiający skazanemu powrót na ziemię (ponieważ jego widmo, jak wierzono, nie potrafi przebyć wody). B a y e t,op. cit. s. 67: $\mathrm{M}$ a g d a 1 in op. cit.,. s. 550.

${ }^{9}$ C. Th. $9.15,1(318):(\ldots)$ ut regionis qualitas tulerit, vel in vicinum mare vel in arnnem priciat!ur (...); tak samo Inst. 4. 18, 6.

${ }_{10}$ Podstawy źródłowe co do stosowania tej praktyki są niepewne; informuje o niej jedynie gramatyk Dositheus (Sent. et epist. Hadr. 3. 16). E. B r u n n e n m e i s t e r, Das Tödtungsverbrechen im altrömischen Recht, Leipzig 1887, s. 188, przyp. 2, uważa, ze ten przekaz. jest apokryficzny. M o m m s e n, op. cit. s. 922. przyp. 9, i C a n t r e 1 1 a, op. cit. s. 284, nie kwestionują świadectwa gramatyka. Wedlug Dülla, op. cit., ss. $369,370,395$, ryt ten poprzez wykorzystanie czarnych wolów nawiązywal do kultu bogów zmarłych i całkowicie pasuje do calego modelu wykonania tej kary. Zdaniem tego autora nie ma podstaw do odrzucenia przekazu Dositheusa. Takim argumentem, zdaniem D ü lla, nie może być milczenie Plautusá i Cycerona w tej kwestii.

11 Cic. p. Rosc. Am. 13, 38.

12 Cic. pro Rosc. Am. 22, 63: portentum atque monstrum.

13 Brunnenmeister op. cit. s. 197; Cantarella op. cit. 285: J, D. $\mathrm{C}$ lo u d, Parricidium: from the lex Numae to the lex Pompeia de parricidis, Zeitschrift der Savigny-Stiftung für Rechtsgeschichte. Romanistische Abteilung 88 (1971), s. 34; $\mathrm{H}$ i $\mathrm{z}$ i g. op. cit. col. 1748; $\mathrm{M}$ a g d a 1 i n, op. cit. s. 550.

14 Jako prodigium w Rzymie traktowano także hermofrodytów. Ich także, jak opisuje Liwiusz $(31,12,8)$ wrzucano do morza: (...) ante omnia abominanti semimares iussique in mare extemplo deportatri, sicut proxime $C$. Claudio $M$. Livio consulibus deportatus similis prodigii fetus erat. Szerzej na temat rytu procuratio prodigi i jego funkcji w religii rzymskiej. zob. R. B I o c h, Les prodiges romains et la, procuratio prodigiorum", w: Mél. F. de Visscher, t. I. Bruxelles 1949, s. 119 nn. 
kołysani przez fale, ale nie są obmywani przez nie; w końcu, po śmierci są wyrzucani na brzeg, ale i tu nie znajdują spoczynku na skałach"'15.

2. Poena cullei została wprowadzona do rzymskiego systemu kar na podstawie zwyczaju , który w pewnym momencie dziejów Rzymu utrwalił się jako obowiazujące prawo. Jurysta Modestyn, w tekście włączonym do Digestów pisze, że kara worka została wprowadzona na podstawie zwyczaju przodków (more maiorum (...) instituta est ${ }^{16}$ ). Podobne stwierdzenie znajdujemy w wypowiedzi Cycerona w mowie w obronie Sextusa Rosciusa $\mathrm{z}$ Amerii ${ }^{17}$. Taka interpretacja genezy kary worka przeważa we współczesnej literaturze ${ }^{18}$.

Wypowiedzi niektórych starożytnych autorów sugerują istnienie jakiejś ustawy, na mocy której wprowadzono poena cullei. Waleriusz Maximus opowiada, że król etruski Tarkwiniusz Wspaniały miał zastosować karę worka wobec duumiwira $\mathrm{M}$. Atliusza, który dopuścil się zdrady tajemnic świętych obrzędów. Później - czytamy w Factorum et dictorum memorabilium - kara ta została wprowadzona jako sankcja za zabójstwo osób bliskich, poena parricidi. I dużo później (multo post), pisze dalej' Maximus, ,ten rodzaj kary śmierci był nakładany przez ustawę na ojcobójców, jako że znieważenie, zbeszczeszczenie (violatio) rodziców i bogów winno być mszczone w ten sam sposób"19. Maximus wspomina zatem o bliżej nieznanej ustawie, mocą której miałby być wprowadzony ten rodzaj kary śmierci. Autor „Rhetorica ad Herennium" cytuje zaś pewien tekst normatywny dotyczący kary za ojcobójstwo: „Ten, kto został skazany za zabójstwo rodzica, owinięty (obvolutus) i zamknięty (obligatus) w bukłak, niech będzie wrzucony do wody (in

${ }_{15}$ Cic. p. Rosc. Am. 26, 72: Ita uiuunt, dum possunt, ut ducere animam de caelo non queant; ita moriuntur ut eorum ossa terra non tangat; ita iactantur fluctibus ut numguam alluantur: ita postremo eiciuntur ut ne ad saxa quidem mortui conquiescant.

16 D. 48, 9, 9 pr: 1 (Modestinus): Poena parricidi more maiorum haec instituta est (r.) Qui alias personas occiderint praeter matrem et patrem et avum et aviam (quos more maiorum puniri supra diximus) (...).

17 Cic. p. Ross. Am. 25, 70: quanto nostri maiores sapientius! Qui, cum intellegerent nihil esse tam sanctum quod non aliquqndo violaret audacia, supplicium in parricidas singulare excogitaverunt $u t$, quos natura ipsa retinere in officio non potuisset, ii magnitudine poenae a maleficio submoverentur. Insui voluerunt in culleum vivos atque ita in flumen deici

${ }_{18}$ Teza, że poena cullei została wprowadzona na podstawie zwyczaju jest dziś powszechnie przyjmowana; do jej zwolenników należą m.in.: B r u n n e $\mathrm{n}$ m e i s t e r, op. cit. s. 186; C a n t a r ella, op. cit. s. $267 \mathrm{nn}$; H i t zig, op. cit. col. 1747; $\mathrm{M}$ a g d a 1 i n, op. cit. s. 550; M. R a d i n, The lex Pompeia and the poena cullei, Journal of Roman Studies 10 (1920), s. 121. przyp. 1.

19 Val. Max. 1, 1, 13: Tarquinius autem rex M. Atilium duumvirium, quod librum secrata ritum civilium sacrorum continentum, custodiae suae commissum corruptus Petronio Sabino describendum dedisset, culleo insutum in mare abici iussit, itque supplicii genum multo post parricidis lege inrogatum est, iustissime quidem, quia pari vindicta parentum ac deorum vilatio expianda est. 
profluentem)"20 . Także inni autorzy, Seneka Filozof, Kwintylian i Tertulian napomykają o bliżej nieznanej ustawie ${ }^{21}$. Wypowiedzi te dały niektórym romanistom podstawę do przyjęcia opinii, że poena cullei została wprowadzona do rzymskiego systemu kar drogą ustawy ${ }^{22}$. Poglądu tego nie da się utrzymść. Źródła literackie nie precyzują bliżej, o jaką ustawę chodziło, przez kogo została ona wprowadzona i od kiedy obowiązywała. Jednak nasuwa to pytanie, jak rozumieć rozbieżność pomiędzy wypowiedzią Modestyna wskazującego mos maiorum jako podstawę poena cullei i źródłami literackim mowiącymi o ustawie?

Otóż mores maiorum, mimo że w sensie technicznym nie były ustawami miały charakter i moc norm prawnych. Rzymianie uważali bowiem, że dane normy istniały jako obowiązujące od bardzo dawnych czasów, z reguły bliżej nie znanych ${ }^{23}$. Tak zatem najprawdopodobniej pisarze, retorzy, zatem osoby, które nie były prawnikami, obowiązujący i od dawna przestrzegany zwyczaj co do stosowania poena cullei nazywali także ustawami nie dociekając jaka była podstawa ich obowiązywalności. Inaczej, w sensie ogólnym nazywali ustawami to, co drogą zwyczaju otrzymało moc obowiązującą ${ }^{24}$.

3. Poena cullei odróżniała się od innych form wykonania kary śmierci $\mathrm{z}$ racji na umieszczanie zwierząt $\mathrm{w}$ worku $\mathrm{z}$ winnym przestępstwa ojcobójstwa; właśnie ta oryginalna w swoim okrucieństwie praktyka uczyniła poena cullei karą nie mającą odpowiednika w starożytności. Oczywiście nasuwa to pytanie, jakie były to zwierzęta i dlaczego właśnie one.

Modestyn pisze, że zgodnie ze zwyczajem przodków sprawca parricidium był zaszywany wraz z psem, kogutem, żmiją i małpą; te same zwierzęta wymieniają Instytucje Justyniana ${ }^{25}$. Kodeks Teodozjański wymienia tylko węża ${ }^{26}$.

Źródła literackie także nie wymieniają zawsze tych samych zwierząt, tak co do ich rodzaju jak też liczby. I tak np. o żmijach w liczbie mnogiej mówią

20 Auct. ad Her. 1, 13, 23: Et lex: Qui parentem neccasse iudicatus erit, obvolutus et obligatus corio, devehatur in profluentem.

${ }_{2} \mathrm{P}$ Sen. de clem. 1, 23, 1: (...) parricidae cum hac lege coeperunt, et illis facinus poena monstravit (...) Quin. decl. 299: (...) cuius statim oräoculosaue a iudicio lex iussit obduci (...); Tertull. ad nat. 2, 13: (...) tunc legibus ageretur, in duos culleos dividi Iovem decuit (...).

Zwolennikami teorii, że najprawdopodobniej poena cullei została wprowadzona na mocy ustawy są m.in.: Düll. op. cit. s. $365 ; \mathrm{M}$ e y I a $\mathrm{n}$, op. cit. s. 31, przyp. 1: s. 45. Innych zwolenników tej hipotezy wymienia $\mathrm{N}$ a r d i, op. cit. s. 59. przyp. 1.

${ }^{23}$ W. L i t e w s k i, Rzymskie prawo prywatne. Historia źródel. Proces cywilny, Kraków 1993, s. 9.

${ }_{24} \mathrm{~B}$ r un ne n m e is t e r, op. cit. s. 187; podobnie N a r di. op. cit. s. 62-63.

25 D. 48. 9, 9 pr. (Modestinus) = Inst. 4, 18, 6 (...) cum cane, gallo gallinaceo et vipera et simia.

26 C. Th. $9,15,1$ : serpentium contuberniis. 
Kwintylian ${ }^{27}$, Seneka retor $^{28}$ i Seneka filozo ${ }^{29}$. O małpie pisze jedynie Juwenalis; w jednej z satyr wymienia ją wraz z wężem ${ }^{30}$, w innej bez niego ${ }^{31}$. Psa i żmiję wspomina Euzebiusz z Cezarei ${ }^{32}$. Hadriani sententiae wspominaly te same zwierzęta co Modestyn, aczkolwiek w nieco innym porządku ${ }^{33}$. Izydor z Sewilli wymienia koguta, żmiję i małpę ${ }^{34}$, te same zwierzęta wylicza bizantyjski kronikarz Cedreno ${ }^{35}$.

Waleriusz Maximus i autor Rhetorica ad Herennium pisząc o wprowadzeniu tej formy kary, nic nie wspominają o konieczności włożenia do worka zwierząt wraz ze skazańcem. Nic na ten temat nie mówi Cyceron. To krótkie i jedynie przykładowe zestawienie wzmianek o zwierzętach towarzyszących ojcobójcy wskazuje, że liczba i rodzaj zwierząt w poszczególnych źródłach nie zawsze były jednakowe. Jak zatem wyjaśnić fakt, że niektóre przekazy mowią jedynie o wężu (lub wężach) a inne wymieniają inne zwierzęta? Dlaczego niektóre teksty literackie mówiące o karze worka nic nie wspominały na temat zwierząt?.

Opinie $w$ tej kwestii sa różne. Niektórzy przypuszczali, że praktyka dołączania zwierząt pochodzi $\mathrm{z}$ okresu późnorepublikańskiego lub nawet cesarskiego. Lista zwierząt natomiast miałaby się rozszerzać powoli, w porządku chronologicznym, poczynając od węża poprzez późniejsze dołączenie małpy, w końcu koguta i psa lub w nieco innej kolejnośći ${ }^{36}$. Niektórzy autrzy chcieli nawet przypisść wprowadzenie praktyki dołączania zwierząt (jednego lub więcej, lub wszystkich czterech) konkretnej ustawie ${ }^{37}$ lub niektórym cesarzom $^{38}$. Hipotezy te słusznie nasuwaja wiele wątṕliwości.

\footnotetext{
27 Quin. decl. 17. 9: quandoque culleo, serpentibus expianda feratis. ,

${ }^{28}$ Sen. cotr. 5, 4, 2: (...) imaginabar mihi culleum, serpentes, profundum; 7, 1, 23: non habui parricidi instrumenta, non culleum, non serpentes.

${ }_{29}$ Sen. de clem. 1, 15, 1: non culleum, non serpentes, non carcerem decrevit (...).

${ }^{30}$ Iuv. 8. 214: (...) simia nec serpens unus nec culleus unus?

31 Iuv. 13, 156: innoxia simia.

32 Euz. de mart. Palaest. 5, 1 (PG 50, 671, t1. fac.): (...) cum in eum scorpiones, vipera et dracones injecisset (...)

33 Dosith. sent. et epist. Hadr. 16: cum vipera et cane et simia et gallo.

34 Isid. or. 5. 27, 36: (...) cum simio et gallo et serpente.

35 Georgii Cedreni. Compendium historiarum (PG. t. 121. 379. tł. łac.): (...) cum gallo, vipera et simia (...).

${ }^{36}$ Zwolennikami takiej tezy jest m.in. R o ndin, op. cit. s. 127 nn., który przyjmuje, że praktyka dołączania zwierząt została wprowadzona w okresie od wydania ustawy lex Pompeia de parrcidis do czasu panowania Konstantyna; podobnie D ü 11 , op. cit. 368 .

$37 \mathrm{H} \mathrm{u} \mathrm{m} \mathrm{bert} \mathrm{op.} \mathrm{cit.} \mathrm{1579,} \mathrm{twierdzi,} \mathrm{ze} \mathrm{to} \mathrm{ustawa} \mathrm{lex} \mathrm{Pompeia} \mathrm{de} \mathrm{parrcidis}$ nakazala umieszczać cztery zwierzęta wraz $\mathrm{z}$ ojcobójcą: podobnic przypuszcza B run ne $\mathrm{nm}$ e is t e r, op. cit. s. 188.

${ }_{38} \mathrm{~Np}$. R a d i n, op. cit. s. 126, przyjmowal, że lex Pompeia ograniczała się jedynie do nakazu włożenia żmiji. Wkładanie do skórzanego worka małpy, traktowanej jako symbol nieludzkiego gestu ojcobójcy, mialby wprowadzić Klaudiusz. Pies i kogut, związane z pogańskimi kultami Mitry, Cibele i Izydy, miałyby być wkładane do culleus $\mathrm{z}$ polecenia Konstantyna. Według innych autorów, np. C. F e r ri n i, Esposizione
} 
Praktyka zaszywania w worku czterech zwierząt, oczywiście w różnych zestawieniach, sięga dawnych czasów i została wprowadzona na podstawie zwyczaju, co wyraźnie potwierdził Modestyn. Proces formowania się tej praktyki miał dynamiczny charakter i jej powstanie nie było efektem prawnej regulacji ${ }^{39}$. Najprawdopodobniej praktyka ta była, w zależności od miejsca i czasu przestrzegana lub nie, lub też przestrzegana częściowo. Zwierzęta te wybierano w zależności od przypadku lub nawet lokalnych możliwości ${ }^{40}$. Prawdopodbnie nie przywiązaywano do tej listy większego znaczenia. Lista obejmująca cztery dzikie zwierzęta stanowi natomiast model końcowy tego procesu tworzenia się zwyczaju. Te okoliczności wyjaśniałyby milczenie niektórych źródeł literackich $\mathrm{z}$ końca republiki o tej praktyce, jak też fakt wyliczania tylko niektórych $\mathrm{z}$ tych czterech zwierząt przez inne źródła. Ten starożytny zwyczaj, który kultywowano przez pokolenia i który uległ utrwaleniu został w końcu usankcjonowany ustawowo ${ }^{41}$.

Pytanie, dlaczego tymi zwierzętami były właśnie żmija, pies, kogut i małpa stanowi bardzo interesujący problem. Zagadnieniu temu poświęcono dużo uwagi, tak w minionych wiekach jak też współcześnie. Efektem tych dociekań, tak romanistów jak historyków religii rzymskiej, jest wiele teorii i hipotez. Można je, w dużym uproszczeniu oczywiście, sprowadzia do trzech zasadniczych grup. Dzikim zwierzętom towarzyszącym ojcobójcy nadawały one znaczenie religijno-magiczne, praktyczne lub symboliczne.

Zwolennicy pierwszej teorii przyjmowali, że zwierzęta umieszczano wraz z ojcobójcą z przyczyn religijno-magicznych. Ponieważ funkcją poena cullei było usunięcie sprawcy okrutnej zbrodni (monstrum) ze świata żywych (procuratio prodigi) $^{42}$ dołączano zwierzęta, które miały znaczenie rytualne. Według takiego objaśnienia pies, kogut, żmija i małpa, niezależnie od swoich cech specyficznych, były włączone do culleus dlatego, że były zwierzętami „strasznymi”, ,potwornymi” (prodigi). Ich włączenie łączyło ojcobójcę $\mathrm{z}$ nimi we wspólnym akcie eliminacji ${ }^{43}$.

storica e dottrinale del diritto romano, Milano 1904, s. 389 nn., wszystkie cztery zwierzęta były przydawane sprawcy ojcobójstwa $\mathrm{z}$ woli cesarza Konstantyna. Szerzej na temat hipotez w tej materii zob. $\mathrm{N}$ a $\mathrm{rd}$ i, op. cit. s. 128 , przyp. 11; 12; s. 129, przyp. 13.

${ }^{39} \mathrm{C}$ a $\mathrm{t}$ a r e ll a, op. cit. s. 267 nn., twierdzi, że praktyka zaszywania zwierząt zrodziła się spontanicznie w okrutnej fantazji tych, którzy zajmowali się egzekucją wyroków. Niezależnie od nakazów normatywnych, zaczęli zaszywać w culleus zwierzęta, które było łatwo znaleźć i które odznaczały się dużą agresywnóscią. W miarę upływu czasu, gdy praktyka ta rozpowszechnila się i ustabilizowala, zwyczaj został potwierdzony przez prawo.

${ }_{40} \mathrm{C}$ a $\mathrm{n} \mathrm{t}$ a r e 11 a, op. cit. s. 268 , shusznie zauważa, że trudno byłoby przypuszczać, że w przypadku skazania ojcobójcy zawsze bylo dostępne takie zwierze jak np. małpa. Owszem, była ona znana w Rzymie od starożytności (D ü 11 . op. cit., s. 392), ale z drugiej strony zapewne była zwierzęciem trudniejszym do znalezienia niż pies, kogut czy żmija.

${ }_{41}$ C a n t a rell a, op. cit. s. 268-269; podobnie $\mathrm{N}$ a r d i, op. cit. s. 129-130.

42 Zob. wyżej. p. 1.

43 R o d i n. op. cit. $123 \mathrm{nn}$. Zwolennikiem takiej tezy, z różnymi zastrzeżeniami jest także D ü 1 l, op. cit. ss. 385-394; 402-404. 
Ta teoria ma swoje słabe strony. $\mathrm{Z}$ samej definicji prodigium ${ }^{44}$ wynikało bowiem, że było to stworzenie mające cechy straszne, budzące grozę. Za takie mogłaby ewentualnie uchodzia żmija. Ale nie można przyjąć, że zwierzęta tak banalne jak pies czy kogut, mogłyby by być uważane za prodigi?.

Przyjęcie tezy, że zwierzę te były istotnie uważane za monstrum powoduje także inną wątpliwość. Mianowicie jaki sens miałoby umieszczanie obok ojcobójcy czterech innych stworzen-monstrum?. Byłoby to niepotrzebnym mnożeniem bytów ${ }^{45}$.

Innym wyjaśnieniem odwołującym się do religijnego znaczenia obecności zwierząt stanowi hipoteza przyjmująca, że pies, kogut i żmija były uważane za zwierzęta chtoniczne, które towarzyszyły w Hadesie podziemnym bóstwom grecko-italskim ${ }^{46}$. Teoria ta nie wyjaśnia jednak znaczenia wszystkich zwierząt?.

Niektórzy autorzy przyjmują, ze dołączenie zwierząt miało cele praktyczne; zaszycie ich wraz ze skazanym miało zwiększyć okrucieństwa tej kary ${ }^{47}$. Bezspornie było to jednym z celów tej praktyki, ale nie jedynym. Nie tylko $\mathrm{z}$ racji na agresywnść tych zwierząt wkładano je do worka. Rzymianie niewątpliwie bez trudu znaleźliby inne zwierzęta bardziej dokuczliwe i agresywne. Wkładano te zwierzęta również dlatego, że w przekonaniu Rzymian posiadały cechy, które czyniły je szczególnie odpowiednimi by towarzyszyć ojcobójcy.

Najbardziej przekonywującym jest wyjaśnienie łącznie wskazujące symboliczne i praktyczne zarazem znaczenie zwyczaju dołączania zwierząt. Otóż stosując miarę antropocntryczną w ocenie charakteru zwierząt Rzymianie uważali psa za zwierzę pogardzane i nieczyste, które mogło być także okrutne dla przedstwicieli swego gatunku ${ }^{48}$. Koguta opisywali jako zwierze agresywne i zwalczjące swoją rasę ${ }^{49}$. Żmije, jak wierzono, rodziły się zabijając

44 Slowo prodigium oznacza potwora, byt nienaturalny i straszny. Lateinisches etymologisches Wörterbuch, red. A. W a l d e - J. B. H o f m a n n, t. II, Heidelberg 1954, v. prodigium, s. 368.

${ }_{45} \mathrm{C}$ a n t a r e 11 a, op. cit., 272; S. T o n d o, Leges regiae e parricidas, Firenze 1973, s. $155 \mathrm{nn}$.

46 B a y e t, op. cit., s. 67. Innym wyjaśnieniem na gruncie magiczno-religijnym była hipoteza, według której zwierzęta, zwłaszcza wąż, były uważane za prześladowców zlych duchów. Tak zatem funkcją tych zwierząt było zwalczanie przestępcy także w życiu pozaziemskim. Ich zadaniem było zatem nie tylko odebranie ziemskiego życia ale także pozbawienie ojcobójcy możliwości przetrwania we formie ducha. T o n d o, op cit. ss. $155 ; 167$. Teoria ta nie znajduje gruntownego uzasadnienia źródłowego.

47 Tak np. utrzymuje $\mathrm{H}$ u m b e r t, op. cit. s. 1579.

48 Plin. n.h. 29, 3; R e i n, op. cit. s. 457; podobnie $\mathrm{C}$ a $\mathrm{n}$ t a r e 11 a, op. cit., s. 269-270; szerzej zob. $\mathrm{N}$ a r d i, op. cit., s. 133, przyp. 6

${ }^{49}$ Kogut, a jak dokładniej precyzują źródła kaplon (gallo gallinaceo) uchodził za zwierze bardzo okrutne i waleczne; zdaniem Pliniusza (n. h. 10, 24; 47 i 48) terroryzowal nawet lwy, C a n t a r e ll a, op. cit., s. 270. Źródla i bibliografię zestawia $\mathrm{N}$ a r d i, op. cit. s. 123 , przyp. 3 ; s. 135 . przyp. 7 . 
matkę $e^{50}$. Małpa zaś mogła uosabiść obrzydzenie, jaḱo obraz zdeformowanego człowieczeństwa ${ }^{51}$.

Te cechy przypisywane przez Rzymian kogutowi, psu, żmiji i małpie, niezależnie od tego czy były prawdziwe czy też fałszywe, i niezależnie od naszych współczesnych ocen charakteru tych zwierząt, wskazywały i charakteryzowały czyn ojcobójcy. Ponadto zwierzęta zamknięte w worku wraz ze skazanym, dopóki pozostawał on przy życiu, atakowały go i gryzły. Po śmierci ich resztki mieszały się ze szczątkami skazanego ${ }^{52}$.

4. Zakres stosowania poena cullei w rzymskim prawie karnym ulegał zmianom. Wprowadzona mocą zwyczaju kara ta została zachowana w ustawodawstwie Sulli; ustawa lex Cornelia de sicariis et veneficiis przewidywała karę worka w przypadku zabójstwa wstępnych ${ }^{53}$. Dyskutowanym jest zagadnienie, czy ustawa lex Pompeia de parricidiis z 55 r. przed $\mathrm{Chr}^{54}$, $\mathrm{która}$ uregulowała postępowanie w przypadku przestępstwa parricidium, zniosła poena cullei? Opinie uczonych są wyjątkowo niezgodne w tej materii.

Według Marcjana, na mocy tej ustawy wszyscy zabójcy krewnych podlegali karze przewidzianej przez lex Cornelia de sicariis ${ }^{5 s}$. Wypowiedź jurysty mogłaby wskazywać, że oznaczało to zniesienie kary culleus za parricidium ${ }^{56}$.

50 Według opisu Pliniusza (n.h. 10, 82: 169 i 170) potomstwo żmiji wychodziło $\mathrm{z}$ boku matki mordując ją. Szerzej zob., $\mathrm{C}$ a n $\mathrm{t}$ a r e $1 \mathrm{l}$ a, op. cit., s. 271 ; $\mathrm{N}$ a r d i, op., cit. s. 136 , przyp. 8.

51 Cic. ad fam. 5, 10, 1; Cic. de nat. deor. $1,35,97$. C a n t a r e 11 a, op. cit. s. 271; $\mathrm{R}$ e i n, op. cit., s. 458. Zródła literackie i bibliografię na ten temat zestawia $\mathrm{N}$ a $\mathrm{r}$ d i, op. cit., s. 137 , przyp. 9.

52 N a r d i, op. cit., s. 142, pisze, że w przypadku gdyby skórzany worek wraz ze szczątkami ojcobójcy zostal zepchnięty na brzeg i znaleziony przez kogokolwiek, zwierzęta spełnialy dodatkową rolę: wyjaśnialy one przyczynę egzekucji. Zdaniem autora, pelniły one taką samą funkcje, jak kwiat $w$ ustach zabitego $w$ egzekucjach mafijnych (nello stesso modo che al fiore in bocca o ad altro nelle asecutioni mafiose).

${ }_{53}$ M o m m s e n, op. cit. s. 644. przyp. 3; H i t z i g, op. cit. col.1747.

54 Datacja ten ustawy jest rożna. Niektórzy (m.in.: C l o u d, op. cit., s. 47. przyp. 52, s. 48; E. L e v y, Die römische Kapitalstrafe, w: Gesammelte Schriften, t. II. Köln-Graz 1963. s. 343; G. R o t o n d i. Leges publicae populi Romani. Hindelsheim 1962, s. 406) przyjmuja, że lex Pompeia de parricidis została najprawdopodobniej ogloszona w 55 r. przed Chr. Inni autorzy (m. in.: B e r g e r, op. cit., v. Lex Pompeia de parricidio. s. 558; D. N ö r r, Causa mortis. München 1986, s. 106) wskazują r. 55 lyb 52 jako datę ogłoszenia tej ustawy. R. 70 jako datę wydania ustawy podają m.in.: D ü 11 , op. cit. s. 366; Prawo rzymskie. Słownik encyklopedyczny, red. W. Wolodkiewicz, Warszawa 1986, v. parricidium, s. 114. Szerzej na temat tej ustawy, zob. L. F a n n i z a, Il parricidio nel sistema della , ,lex Pompeia”, Labeo 25 (1979), z 3. s. $266 \mathrm{nn}$.

${ }_{55}$ D. 48, 9, 1 (Marcianus): ut poena ea teneatur, quae est legis Corneliae de sicariis.

${ }^{56}$ Tak m.in. utrzymuje $M$ om m s e n, op. cit. s. 644, przp. 2: twierdzi on mianowicie, że wprowadzenie tej ustawy oznaczało całkowite zniesienie kary śmierci w przypadku parricidium (vollständge Abschaffung der Todesstrafe). Por., tamże, s. 201; 942; podobnie D ü 11, op. cit. s. 366 . Teza ta znajdowałaby potwierdzenie w niektórych źródłach literackich. Wedlug świadectwa Swetoniusza (Caes, 42), za zabójstwo Cezar karał konfiskatą wszystkich dóbr. Zdaniem C l o u d a, op. cit. s. 47 
Źródła literackie jednak wskazują, że w niedługim czasie po ogłoszeniu lex Pompeia de parricidiis kara worka była nadal wykonywana. Swetoniusz opisuje, że karę tę wykonywano w czasie panowania cesarza Augusta ${ }^{57}$. Także Seneka, tak ojciec jak syn mówią o jej stosowaniu ${ }^{58}$.

Pewne modyfikacje w tej materii wprowadził cesarz Hadrian. W przypadku zabójstwa rodziców i dziadków nakazał on stosować poena cullei, ale jedynie w tych przypadkach, jeśli morze znajdowało się w pobliżu (si mare proximum sit) $)^{59}$ W innych sytuacjach skazani byli wydawani dzikim zwierzętom (alioquin bestiis obicitur) ${ }^{60}$.

Pod koniec pryncypatu poena cullei wyszła $\mathrm{z}$ użycia. Kara śmierci za przestẹpstwo parricidium była wykonywana przez spalnie lub wydanie dzikim zwierzętom ${ }^{61}$. W okresie cesarstwa tę starą formę kary przywrócił cesarz Konstantyn mocą konstytucji z 318 r. (C. Th. 9, 15, 1) adresowanej do Werinusa, wikariusza Afryki ${ }^{62}$.

Ustawa ta, która sama jedyna stanowi tytuł „De parrcidis” dziewiątej księgi Kodeksu Teodozjańskiego, regulowała sposób wykonania kary

nn., lex Pompeia de parricidiis zniosła culleus i zrównala parricidium z zabojstwem (homicidium), F a $\mathrm{n}$ i z z a, op. cit. s. 278, przyp. 33, polemizując $\mathrm{z}$ opinią $\mathrm{Cl}$ o u d a twierdzi że ustawa lex Pompeia de parricidiis nie wykluczała kary worka w przypadku parricidium. Z kolei Levy, op. cit., s. 343, przyjmuje, że w przypadku orzekania kary za zabójstwo osób bliskich sędzia zupełnie nie był ograniczony w wyborze rodzaju śmierci.

57 Historyk pisze, że w tym czasie na kare worka skazywano oskarżonego w przypadku ,,jawnego ojcobójstwa" i w wypadku przyznania się oskarżonego do winy. Suet. Aug. 33: (...) manifesti parricidii reum, ne cuello insueretur, quod non nisi confessi adificintur hac poena, ita fertur interrogasse: "Certe patrem tuum non occidistii?». Zob. także $\mathrm{H}$ i tz i g, op. cit. col. 1747; Clo u d, op. cit. s. $58 ; 62$ . F a $\mathrm{n}$ i z z a, op. cit. s. $280 \mathrm{nn}$. Zdaniem D ü 11 a, op. cit. s. 403, poparcie Augusta dla tej starej formy kary było zgodne $\mathrm{z}$ jego reformatorskim działaniem $\mathrm{w}$ dziedzinie obyczajów i religii rzymskiej.

58 Sen. de clem. 1, 23, 1: «Pater tuus plures intra quinguennium culleo insuit, quam omnibus saeculis insutos accepimus»; tamże, 1, 15, 7: Non culleum, non serpantes, non carcerem decrevit memor, non de quo censeret, sed cui in consilio esset; mollissimo genere poenae contentum esse debere patrem dixit in filio adulescento; Sen. contr. 7, 2, 3: (..) si damnatus esses, carnifex te culleo tum insuisset.

59 D. $48,9,9$ pr.

60 Tamże.

61 Paul. Sent. 5, 24: Lege Pompeia de parricidiis [tenentur]qui patrem matrem auum auiam fratrem sororem patronum patronam occiderint, etsi antea insuti culleo in mare praecipitabantur, hodie tamen uiui exeruntur uel ad bestias dantur.

62 C.Th. 9. 15. 1. Imp. Constantinvs. A. ad Verinvm vic (carium Africa (ae). Sie quis in parentis aut filii aut omnino affectionis eius, que nuncypatrione parricidii continentur, fata properaverit, sive clam sive palam id fuerit enisus, neque gladio neque ignibus negue ulla alia sollemni poena subiugetur, sed insutus cuello et inter eius ferales anguestias conprehensus serpentum contubebeniis misceatur et. ut regionis gualitais tuierit, vel in vicinum mare vel in amnem proiciatur ut omni elementorum usu vivus carere incipiat, ut ei caelum superstiti, terra mortuo auferatur. 
śmierci wobec zabójcy osób bliskich (ojca, syna i innych krewnych) ${ }^{63}$. Ustawa zagrażała sprawcy parricidium, kimkolwiek by on nie był, wyłącznie karą culleus ${ }^{64}$. Ustawa precyzowała to bardzo dokładnie, wykluczając inne sposoby egzekucji kary śmierci: ścięcie mieczem, spalenie (neque gladio, neque ignibus) lub inne zwykłe kary (neque ulla alia solemni poena subiugetur). Rozstrzygnięcie to zostało dodatkowo wzmocnione dyspozycją, że gdyby $z$ racji na charakter regionu, nie było możliwe wrzucenie worka ze skazanym do morza, należało go wrzucia do rzeki: $u t$ regionis qualitas tulerit, vel im vicinum mare vel in amnem proiciatur. Dyspozycja ta nabiera szczególnego znaczenia w porównaniu z zasadą przyjętą przez Hadriana, a wspominaną w tekście Modestyna (D. 48, 9, 9), że ilekroć morze nie znajdowałoby się w pobliżu, można było zastosować inną formę wykonania kary śmierci.

Lektura tej ustawy dosyć spontanicznie nasuwa pytanie o doktrynalne motywy jej ogłoszenia. Niektórzy autorzy przyjmowali, że jej wydanie było przejawem rozwoju tendencji barbarzyńskich w ustawodawstwie Konstantyna $^{65}$. Inni jej wydanie wiązali z rozluźnieniem systemu sankcji karnych za zabójstwa ${ }^{66}$. Nie negując wcale tych przyczyn można wymienić inne pobudki jej ogłoszenia; wyraźnie wskazuje na nie tekst ustawy.

Retoryka tekstu ustawy, mimo że został ona zredagowany w zwykłym biurokratycznym stylu, odwoływała się do sakralnego charakteru kary. Podkreśla to następujący fragment konstytucji: ,ut omni elementorum usu vivos carere incipiat, ut ei coelum superstiti, terra mortuo auferetur".

Dyspozycje, aby zabójca osób bliskich nie spoczałł w ziemi po śmierci (terra mortuo auferetur należy interpretować jako wolę pozbawienia skazanego prawa do pochówku ${ }^{67}$. Niewątpliwie stanowiło to jeden, chociaż nie jedyny cel ustawy. Prócz tego bowiem ustawa precyzowała, aby skazany za życia przestał używać wszystkich żywiołów i aby został pozbawiony światła dziennego ${ }^{68}$. I mimo, że ta ustawa została ogloszona $w$ okresie kiedy

${ }^{63}$ Według tekstu ustawy przestępstw to stanowiło zabójstwo ojca, syna, oraz omnino affectionis eius, que nuncupatione parricidi continetur. Zdaniem $\mathrm{K}$ u $\mathrm{p}$ is $\mathrm{z} \mathrm{e}$ w.s k i e g o, op. cit., s. 610, ustawa ta nie określała liczby osób, których zabojstwo stanowilo parricidium. Inaczej $\mathrm{C}$. D u $\mathrm{p}$ o $\mathrm{n} \mathrm{t}$, Le droit criminel dans les constitutions de Constantin, Lille 1953,s. 32, która utrzymuje, że Konstantyn jako parricidium traktował zabójstwo rodziców, dziecka i patronów. Zdaniem autorki, zabójstwo innych bliskich osób Konstantyn kwalifikował jako homicidium.

${ }^{64}$ Kwalifikując zabójstwo syna jako parricidium Konstantyn, jak powszechnie przyjmuje się w literaturze mocą tej konstytucji formalnie obalił ius vitae ac necis przysługujace ojcu rodziny (pater familias. Zob. B. B i o n d i, ll diritto romano cristiano, t. III. Milano 1954, s. 14: K a s e r, op. cit. t. II, s. 204. literaturę dotyczącą zagadnienia jest zestawiona, tamże, przyp. 12.

${ }^{65} \mathrm{Cl}$ o u d, op. cit., s. 58 .

66 B i o n d i, op. cit. t. III, s. 486.

${ }^{67}$ Tak właśnie objaśnia tę dyspozycję Interpretatio do tej ustawy: ut tali poena damnatus nullo tempore obtineat sepulturam.

${ }^{68}$ Taką samą interpretację podają Instytucje Justyniana $(4,18,6)$. 
chrześcijaństwo zostało uznane przez państwo sformułowanie to stanowiło wyraźne odwołanie sie do pierwotnej funkcji tej kary jako aktu procuratio prodigit ${ }^{69}$.

5. Źródła literackie podają, że poena cullei, kara nakładana przede wszystkim na sprawców parricidium była także stosowana w innych przypadkach, różnych od zabójstwa osób bliskich. I tak np. Maximus opisując pierwszy przypadek zastosowania tej kary podaje, że Tarkwiniusz Wspaniały miał ją nałożyć za zdradę tajemnic obrzędów religijnych ${ }^{70}$. Stosowano ją także wobec pierwszych chrześcijan ${ }^{71}$ Euzebiusz z Cezareii relacjonuje w De martyribus Palestinae, że podczas prześladowań $w$ Tyrze za panowania cesarza Maksymina na karę worka został skazany chrześcijanin o imieniu Ulpianus. Został on, jak pisze historyk, razem z psem i żmiją (aspidą) zaszyty w surową skórę wołową i wrzucony do morza ${ }^{72}$. Jan Chryzostom natomiast opisując męczeństwo św. Juliana powiada, że został on umieszczony w worku skórzanym wraz ze skorpionami i wężami i wrzucony do morza ${ }^{73}$; o tej formie kary wspomina legenda dotycząca Marii Magdaleny przytoczona przez bizantyjskiego kronikarza Cedreno w kronice Compendium historiarum ${ }^{74}$.

69 D ü 11, op. cit,. s. 404. R. M a r $\mathrm{t}$ i n i, Sulla constituzione di Constantino in tema di parricidio (C. Th. 9. 15, 1). Accademia romanistica constantiniana. Atti II Convegno internazionale. Perugia 1975, s. 116-117, przyjmuje tezę, szerzej jej jednak nie uzasadniając, że Konstantyn pozbawiając skazanych ,,widoku nieba" inspirował się przesłankami religijnymi, mającymi odniesienie do kuktu Słońca lub nawet Mitry.

70 Zob. wyżej. przyp. 19.

71 Zdaniem T o n d o, op. cit. s. $191 \mathrm{nn}$., motywacją zastosowania tej formy kary wobec chrześcijan były racje doktrynalne. Wrzucenie ciał do wody oznaczało ich zniszczenie, czego chrześcijanie bardzo się lękali. Wierząc $w$ bliski koniec świata i oczekując związanego $\mathrm{z}$ nim zmartwychwstania ciał chcieli sobie zapewnić przechowanie doczesnych szczątków.

72 Euzab. de mart. Palaest. 5 (PG. t. 20.1478 tekst grecki: 1478 tł. łac.): Per idem tempus issdemgue pene diebus in urbe Tyro adolescens quidam Ulpianus nomine, post crudeles plagas ac acerbissima flagrorum verbera, in mare praecipitataus est. Euzebiusz (tamże) 1479) pisze dalej, że taka sama kara spotkała Ajdesjosa, brata Ulpiana: (...) post haec multiplices tormentorum cruciatus fortiter perpessus, tandem in mare praecipitatus, eodem quo frater genere mortis interiit.

73 Jan Chryzostom, In s. Julianum martyrem, 3 (PG. t. 50. 671; t1. łac.): Allato sacco, et arena completo, cum in eum scorpiones, vipereas et dracones injecisset cum illis et sanctum injecit. et in mare demisit.

${ }_{74}$ Kronikarz bizantyjski Cedreno w swojej kronice Compendium historiarum przytacza legendę, według której Piłat miał skazać na karę worka Marię Magdalenę. Zaszyto ją, pisze kronikarz, wraz z kogutem, wężem i małpą a następnie wrzucona do morza. ,jak to Rzymianie mieli w zwyczaju": Pontius Pilatus, imperante C. Caesare, ut Romanorum rerum scriptore perhibent, variis calamitatibus circumventus manus sibi attulit. Alii aiunt eum apud Caesarem Christi causa accusatum a Maria Magdalena, pelli recens bovi detractae insutum una cum gallo, vipera et simia, ut est Romanis consuetudo, radiisque solis expositum perisse (Georgii Cedrini, Compendium historiarium, PG. 1 . 121,379 , tł. łac.). 
We wspomnianych przypadkach poena cullei stanowiła karę za przestępstwa religijne. Jednak informacje dotyczące ich wykonania pochodzą ze źródeł literackich. Jedyną ustawą, która przewidywała zastosowanie poena cullei w innych niż parricidium przypadkach była konstytucja wydana imieniem Konstancjusza i Konstansa w $\mathbf{3 3 9}$ r. Karą tą zostało zagrożone przestępstwo adulterium $^{75}$.

Celem tej ustawy było zaostrzenie sankcji karnych za przestępstwo cudzołóstwa co przejawiało się $w$ dwu dyspozycjach. Przede wszystkim w przypadku orzeczenia winy $z$ tytułu adulterium, sprawcom przęstępstwa nie przysługiwało prawo do apelacji ${ }^{76}$. Nadto zaostrzony został sposób wykonania kary śmierci, sankcji która począwszy od III w. była orzekana za to przestępstwo. Kara śmierci, stanowiła ustawa, winna być wykonana w taki sposób jak w przypadku parricidium, tj. poprzez zaszycie w skórzanym worku i wrzucenie do wody lub przez spalenie (insuere culleo vivos vel exuere).

Przyrównanie do siebie tych dwóch kategorii przestępstw i zastosowanie tej kary wobec sprawców adulterium, w ustawie zakwalifikowanych jako sacrilegi nuptiarum, budzi pewne zdziwienie. Poena cullei nie znajdowała się nigdy w systemie kar za to przestępstwo ${ }^{77}$; zestawienie tych dwóch kategorii przestępstw było najprawdopodobniej przypadkowe. Jaki bowiem mógłby być związek pomiędzy tymi dwoma grupami osób?

Jeśli chodzi o samą technikę wykonania kary, ustawa milczy na ten temat ograniczając się jedynie do stwierdzenia, że winni przestępstwa adulterium winni być zaszyci żywi w worku lub spaleni (insuere culleo vivos vel exuere). Czy więc w przypadku zastosowania poena cullei wraz ze sprawcą adulterium zaszywano w worku jakieś zwierzęta? Przede wszystkim omawiana ustawa, jak rónież inne źrodła prawne, nic nie wspominają na ten temat. Takich

${ }^{75}$ C. Th. 11, 36. 4: Impp. Constantive et Constans AA. Ad Catvlinum. Oportuerat te publici instituti respectu confessione detectos legum severitate punire nec frustra vitam differentum moratorias provocationes admittere, sed delatum adulterii crimen et quaestionibus athibitis convenit observari, ut manifestis probationibus adulterio probato frustratoria provocatio minime admittatur, cum pari similiquje ratione sacrilegions nuptiarum tamquam manifestos parricidas insure culleo vivos vel exuere iudicantem oporteat.

76 Omawiana ustawa została zamieszczona w tytule C. Th, 11. 36: Qarum appelationes non recipiantvur.

77 Przestępstwo adulterium (cudzołóstwo) początkowo nie było ścigane przez państwo lecz było sądzone przez sądy domowe. Do przestępstw publicznych zostafo zaszeregowane przez ustawodawstwo Sulli a następnie przez ustawę Lex Iulia de adulteris coercendis wydaną w $18 \mathrm{r}$, przed $\mathrm{Chr}$. na wniosek Augusta. Ustawa julijska powołała specjalne sądy questiones perpetuae do ścigania winnych adulterium. Za przestępstwo groziła kara wygnania polączona $\mathrm{z}$ utratą praw obywatelskich i konfiskatą polowy lub 1/3 majątku (Paul. Sent. 2, 26, 14). W okresie cesarstwa sankcje za to przestępstwo zostały zaostrzone do kary śmierci wlącznie, o czym m.in. świadczy omwiana ustawa. M o m m s e n, op. cit. s. $694 \mathrm{nn}$. Szerzej na temat sakcji karnych za przestępstwo adulterium, zob. B. B i o n d i, La poena adulterii da Augusto a Giustininiano, w: tegoż, Scritti qiuridici, t. II, Milano 1965, s. $47 \mathrm{nn}$. 
wzmianek, które pozawalałyby przypuszczać, że taka praktyka miała miejsce nie znajdujemy także w źródłach literackich. Po wtóre dołączenie psa, żmiji, koguta i małpy do sprawcy adulterium, zważywszy na ich symboliczne znaczenie obok zabójcy osób bliskich, nie miałoby sensu.

Ustawa nie wskazuje uzasadnień ideologicznych zastosowania tej kary wobec sprawców adulterium. Z jej brzmienia nie można wnioskować, że kara w tym przypadku miałaby jakieś religijne znaczenie.

Tekst ustawy mówi o culleus jako alternatywnej formie wykonania kary śmierci. Z brzmienia tej ustawy wynika, że culleus jako zamienna forma kary mogła być stosowana zarówno wobec sprawców adulterium jak i parricidium. Dyspozycja ta była zatem sprzeczna z ustawą Konstantyna z 318, która wyraźnie zamierzała taką alternartywę wyłączyć. Oznaczało to zatem odwołanie przez Konstancjusza i Konstansa, przynajmniej domyślne, ustawy wydanej zaledwie kilkanaście lat wcześniej; rodzi to pytanie o przyczyny takiej decyzji. Należy raczej wykluczyć, że Konstancjusz i Konstans nie znali ustawy z $318 \mathrm{r}$. Jedynym wyjaśnieniem jest przypuszczenie, że władcy po prostu zignorowali konstytucje swojego ojca ${ }^{73}$. Najprawdopodobniej przyczyną tego był fakt, że w swojej ustawie odnosili się oni do istniejącej prakytyki karania sprawców parricidium zaszyciem w worku lub przez spalenie. Dowodzi to, że po r. 318, przynajmniej w Afryce (obie ustawy były adresowane do wikariuszy Afryki), praktyka zamiennego zastosowania tych kar była nadal stosowana.

Tak zatem poena cullei jako kara za parricidium w Rzymie nigdy nie została ustawowo zniesiona, chociaż za panowania Hadriana była stosowana alternatywnie a pod koniec pryncypatu wyszła z użycia. Początkowo kara ta była traktowana jako akt religijny procuratio prodigii. Ślad tego pierwotnego aspektu kary został zachowany także w ustawie Konstantyna przywracającej tę sankcje, mimo że została ona ogłoszona w okresie, kiedy nowa monoteistyczna religia była już uznana przez państwo rzymskie.

\section{Poena cullei im römischen Strafrecht}

Die Strafe der Säckung (poena cullei), die das Thema dieses Artikels ist, war in Rom eine Form der Vollziehung der Todesstrafe. Sie stand darin, daß der Hinzurichtende mit den Tieren (Schlánge, Affe, Hund, Hahn) in eine Sack genäht und ins Meer oder in einen Fluß geworfen wird. Diese Strafe wurde vor allem für Verwandtenmord (parricidium) eingeführt; die Anwendung für andere Fälle war selten. Ein Verfasser bespricht die symbolische Bedeutung der Tierbeigaben und des Gübrigen Rituals, die der Vollstreckung begleitet haben, den Grund der Einführung der poena cullei in römisches Strafsystem, die betreffende diese Straffe Änderung der Gesetzgebung und Strafe und Anwendungsbereich in der Kaiserzeit.

${ }_{78}$ M a r t in i, op. cit. s. 114; podobnie $\mathrm{N}$ a r d i, op. cit. s. 53. przyp. 10. 